\title{
Determination of bromate in bottled water marketed in Iran by ion chromatography
}

\author{
Sima Djam $\oplus^{1}$, Mostafa Najafi $\odot{ }^{1}$, Seyyed Hamid Ahmadi $\oplus^{2}$ and \\ Shahram Shoeibi ${ }^{*}$ \\ ${ }^{1}$ Department of Chemistry, South Tehran Branch, Islamic Azad University, Tehran, Iran \\ ${ }^{2}$ Department of Environmental Analytical Chemistry, Chemistry \& Chemical Engineering \\ Research Center of Iran, Tehran, Iran \\ ${ }^{3}$ Iran Food and Drug Administration (IFDA), Ministry of Health and Medical Education \\ (MOHME) Tehran, Iran
}

(Received October 02, 2019; Revised October 30, 2019; Accepted November 03, 2019)

\begin{abstract}
Bottled water is common in most countries in the world. According to high consumption and widely consumers from children to older adults safety of it is very important. Bromate $\left(\mathrm{BrO}_{3}{ }^{-}\right)$is one of the most important contaminants in bottled water which national and international standards have set permissible level (10 $\mu \mathrm{g} / \mathrm{L}$ ). In this study, 168 samples of bottled water (mineral and drinking based on Iranian national standard classification) from Iran's market were collected and analyzed for bromate content. Ion chromatography with conductivity detector was applied for chemical analysis. $23.8 \%$ of samples had bromate content upper than allowable level. For mineral water 23 samples and for drinking water 17 samples had bromate as $37.04 \pm 18.62$ $\mu \mathrm{g} / \mathrm{L}$ and $33.58 \pm 15.12 \mu \mathrm{g} / \mathrm{L}$, respectively. According to the origin of bottled waters, their bromide content and other related conditions, it is necessary for health authorized organizations to routinely control and also awareness of consumers for hazards of bromate.
\end{abstract}

Keywords: Bromate; bottled water; disinfection by-products (DBPs); ion chromatography; oxyhalide. (C) 2019 ACG Publications. All rights reserved.

\section{Introduction}

In a few years, bottled water has become very common and popular all over the world. In many countries, bottled water is prepared from purified underground or spring water without any change. According to the European Union (EU), bottled water includes natural mineral water, spring water and other drinking water [1]. Mineral water is referred to bottled water which is used for human consumption without any additives [2]. Based on the definition of Iran's national standard organization (ISIRI), bottled water could contain natural or added minerals as well as $\mathrm{CO}_{2}$, but any added sweeteners or flavors are not authorized. Sources of bottled water are groundwater which is originated from aquifers such as springs, artesian wells, wells and subterranean canals. Also, normal glacier and water supply networks may be used for bottled water. According to ISIRI, bottled water is categorized into two types; mineral and drinking bottled water which must be free from any foreign materials such as hair, sand, insects, etc. [3].

\footnotetext{
* Corresponding author: E-Mail: sh.shoeibi@fda.gov.ir 
There are special regulations for drinking and mineral bottled water [4]. Also, people would like to be assured of the safety and quality of bottled water. There are some contaminations in bottled water, such as dangerous microbial, organic, and inorganic chemicals.

Disinfection is the process by which pathogen microorganisms are eliminated by chemicals (chlorination and ozonation) or physical (UV treatment) methods. By-products may be formed during such processes. Disinfectants may react with natural compounds in water and produce certain chemical compounds that are potentially harmful to human health $[5,6]$.

Risk management of disinfectants is one of the most important factors for water suppliers. While disinfectants are used in water to increase product safety, they may react with special compounds in water thereby forming by-products which are detrimental to human health $[7,8]$. Oxyhalides are one of these compounds which are produced from halogens in water and may be harmful to humans $[9,10]$. Formation of oxyhalides depends on various parameters such as $\mathrm{pH}$, halogen content, contact time, and the concentration of disinfectants. Oxyhalides are not easily separable from water by routine methods $[11,12]$. One of the most important oxyhalides in water is bromate, which has been recognized as carcinogenic for mammals. $\mathrm{BrO}_{3}^{-}$is formed during water disinfection from water content $\mathrm{Br}$ as described below:

(1) $\mathrm{Br}^{-}+\mathrm{O}_{3}+\mathrm{H} 2 \mathrm{O} \rightarrow \mathrm{HOBr}+\mathrm{O}_{2}+\mathrm{OH}^{-}$

(2) $\mathrm{HOBr}+\mathrm{H}_{2} \mathrm{O} \rightarrow \mathrm{H}_{3} \mathrm{O}^{+}+\mathrm{OBr}^{-}$

(3) $\mathrm{OBr}^{-}+2 \mathrm{O}_{3} \rightarrow \mathrm{BrO}_{3}^{-}+2 \mathrm{O}_{2}$

It is also formed by UV photochemical of bromide anion oxidation in chlorinated water [13]. In special conditions, the $\mathrm{HClO}_{2}^{-}$solutions may be caused by $\mathrm{BrO}_{3}{ }^{-}$formation [14]. The formed $\mathrm{BrO}_{3}{ }^{-}$in water is stable at room temperature and is not destroyed by boiling or evaporation [15].

Researchers have found that a reaction between $\mathrm{O}_{3}, \mathrm{Br}^{-}$and $\mathrm{HOBr}$ is slow in lower temperatures, but highly depends on $\mathrm{pH}$ and $\mathrm{Br}^{-}$concentrations [16]. Usually, the content of bromide in water is rare, about $0.5 \mathrm{mg} / \mathrm{L}$. It is naturally found in water at similar concentrations as $\mathrm{Na}^{+}, \mathrm{K}^{+}$, and other cations salts [17].

Routine methods like sedimentation (precipitation), ion exchange and membrane filters can separate bromide from water [11].

Elevated concentrations of $\mathrm{NaClO}$, as a disinfectant, in drinking water may lead to the formation of $\mathrm{BrO}_{3}$. The bromide present in water reacts with both $\mathrm{Cl}^{-}$and $\mathrm{NaOH}$ to form $\mathrm{HClO}$, hence rapidly converting to $\mathrm{BrO}_{3}{ }^{-}$. In basic $\mathrm{pH}\left(10-15\right.$ percent $\mathrm{HClO}$ has a $\mathrm{pH}$ of about 13), $\mathrm{BrO}_{3}^{-}$is formed, remains stable and is not eliminated [18]. One of the suggested methods for $\mathrm{BrO}_{3}{ }^{-}$reduction is by using activated charcoal [19].

The International Agency for Research on Cancer (IARC) categorized $\mathrm{BrO}_{3}{ }^{-}$in the $\mathrm{B} 2$ class which means that it poses a possible risk for human carcinogenicity [20]. Its maximum residual level (MRL) was set by The World Health Organization (WHO) and the Environmental Protection Agency (EPA) as $10 \mu \mathrm{g} / \mathrm{L}$ [5]. The EU has set its MRL at $3 \mu \mathrm{g} / \mathrm{L}$ for natural mineral water and ozonized spring water [21]. Although this amount is based on measurability or elimination, research shows that even 1 $\mu \mathrm{g} / \mathrm{L}$ or less can increase the risk of carcinogenicity $[18,22]$.

Due to high production and interest of consumers to use bottled water at home, at work and within communities, it is necessary to consider product safety from different aspects. In the present study, to the best of our knowledge, different brands of drinking and mineral bottled water were collected from Iran's market and analyzed by ion chromatography (IC) for the first time to determine and quantify $\mathrm{BrO}_{3}{ }^{-}$. 


\section{Experimental}

\subsection{Apparatus and Parameters}

The IC system was a Metrohm Series 7000 (Switzerland) equipped with Metrohm 732 conductivity detector. Chromatographic separations were conducted in Dionex IonPac AS23 $(250 \mathrm{~mm} \times$ $4.0 \mathrm{~mm})$ using an AG23 pre-column $(50 \mathrm{~mm} \times 4.0 \mathrm{~mm})$. The mobile phase for bromated separation including buffer solution of $4.2 \mathrm{mM} \mathrm{Na} \mathrm{CO}_{3}$ and $1 \mathrm{mM} \mathrm{NaHCO}_{3}$, which was prepared by dissolving $0.445 \mathrm{~g} \mathrm{Na}_{2} \mathrm{CO}_{3}$ in $1000 \mathrm{ml} \mathrm{DDW}$ and $0.084 \mathrm{~g} \mathrm{NaHCO}_{3}$ in $1000 \mathrm{ml} \mathrm{DDW}$. Then the buffer solution was degassed and filtered by a $0.45 \mu \mathrm{m}$ nylon membrane filter. The flow rate and temperature were set to 1.1 $\mathrm{ml} / \mathrm{min}$ and $25^{\circ} \mathrm{C}$, respectively. The total run-time was $27.0 \mathrm{~min}$, and the injection loop volume was 20 $\mu l$. In these conditions, bromate retention time was recorded to be $6.8 \mathrm{~min}$.

\subsection{Materials and Preparation}

Sodium carbonate and sodium bicarbonate were purchased from Merck (Germany). The double distilled water (DDW, $18 \mathrm{M} \Omega \mathrm{cm}$ at $25^{\circ} \mathrm{C}$ ) was prepared via Ultra- Pure ELGA Pure Lab (UK). All volumetric flasks and glassware for the sample preparations were of class $\mathrm{A}$.

The stock standard solutions of $\mathrm{BrO}_{3}^{-}$was fabricated at a concentration of $1000 \mathrm{mg} / \mathrm{L} \mathrm{in} \mathrm{DDW}$ and stored at $4{ }^{\circ} \mathrm{C}$. Furthermore, the working standard solutions were prepared by proper daily dilution of the stock standard solution with the DDW. All dilution and preparation of standard solutions were done with double distilled

\subsection{Optimization of Chromatographic Condition}

To find the optimum condition for analysis, type of column, mobile phase concentration, and flow rate and loop volume were evaluated in different conditions. Two columns of Metrohm Metrosep A Supp $5(250 \mathrm{~mm} \times 4.0 \mathrm{~mm})$ and Dionex IonPac AS23 $(250 \mathrm{~mm} \times 4.0 \mathrm{~mm})$ were tested. The Dionex IonPac AS23 had a sharpness and higher resolution chromatography for the $\mathrm{BrO}_{3}{ }^{-}$peak. The concentration of the buffer composition and loop volume were also tested and the optimum conditions were chosen for them as well.

\subsection{Calibration Curve}

The bromate solution at $1 \mathrm{mg} / \mathrm{L}$ was prepared and used for the preparation of five different solutions $(5,10,15,20,31.75$ and $62.5 \mu \mathrm{g} / \mathrm{L})$. Each concentration was injected into the IC three times a day and on three different days.

\subsection{Sample Preparation}

Samples of different bottled water brands were collected from the market. 167 samples of mineral and drinking water bottled in polyethylene terephthalate (PET) were collected and filtered through a $0.45 \mu \mathrm{m}$ membrane filter.

\section{Results and discussion}

The optimum conditions to analyze bromate in bottled water are shown in Table S1. As explained before, to achieve optimum analysis parameters by IC, different parameters were evaluated, and proper conditions were chosen. These conditions were evaluated for better resolution and separation of bromate from another interference anions and also good sharpness of peak and chromatogram.

After optimizing analysis factors, standard solutions of bromate in six concentrations were prepared, measured, and linearity between concentration and responses [Area Under Curve (AUC)] were calculated. Figure S1 displays the calibration curve of bromate which is analyzed by IC. The $\mathrm{r}^{2}$ was in the acceptable range of 0.998 . The acquired data was triplicated and repeated in 3 different days to obtain reliable and competent results which could be repeated and reproduced. 
The chromatogram of anions that was detected by the ion chromatography with conductivity detector and the peak of bromate was shown in Figure 1. Bromate peak under the optimized conditions appeared in $6.8 \mathrm{~min}$. The chromatogram of one of the samples by bromate content of $48 \mu \mathrm{g} / \mathrm{L}$, is shown in Figure 1. In this sample the chloride (which may interfere with bromate in the chromatogram) content was the highest level in the tested samples as $49.8 \mathrm{mg} / \mathrm{L}$ and has not affected on bromate peak, so the separation of the interference anions were acceptable and satisfied.

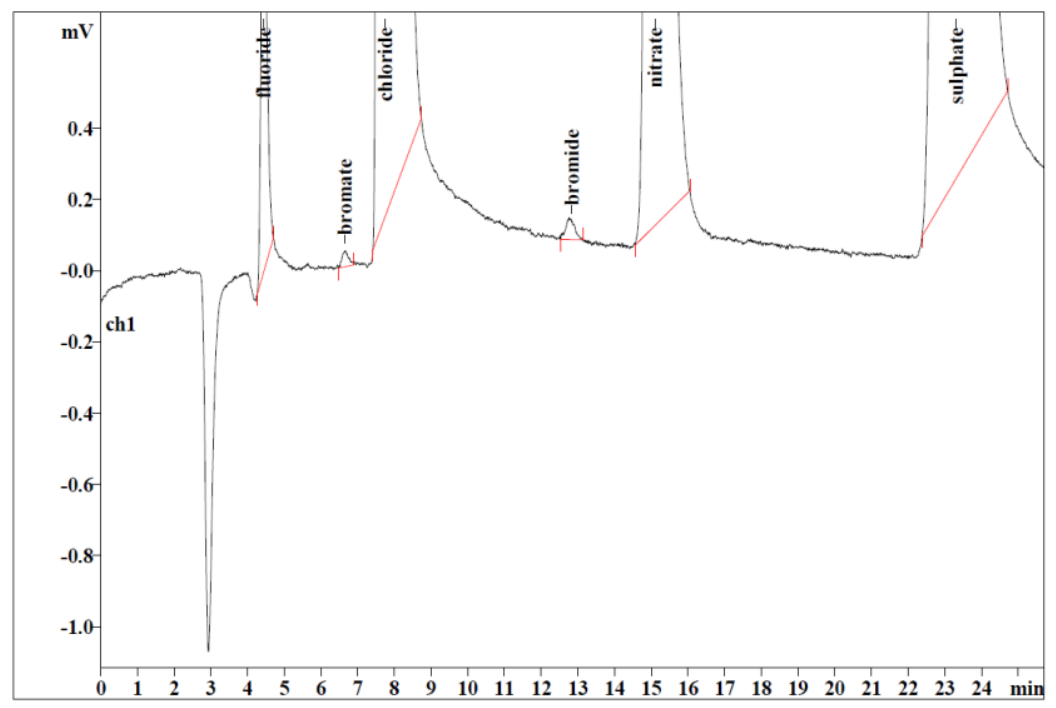

Figure 1. Chromatogram of bromate in bottled water sample $(48 \mu \mathrm{g} / \mathrm{L})$ with higher than MRL $(10 \mu \mathrm{g} / \mathrm{L})$

The 168 collected samples of bottled water, consisting of mineral and drinking water, were analyzed to bromate content. Samples belonged to popular manufacturer brands. Some manufacturers occasionally produce depending on the season. Forty samples $(23.8 \%)$ were observed to have bromate higher than the permitted limit set by international standards $(10 \mu \mathrm{g} / \mathrm{L})$, of which 23 samples were mineral water, and 17 samples were drinking water. The amount of bromate in mineral and drinking water were $37.04 \pm 18.62 \mu \mathrm{g} / \mathrm{L}$ and $33.58 \pm 15.12 \mu \mathrm{g} / \mathrm{L}$ respectively. Figure 2 shows the amount of bromate in mineral and drinking water samples separately.

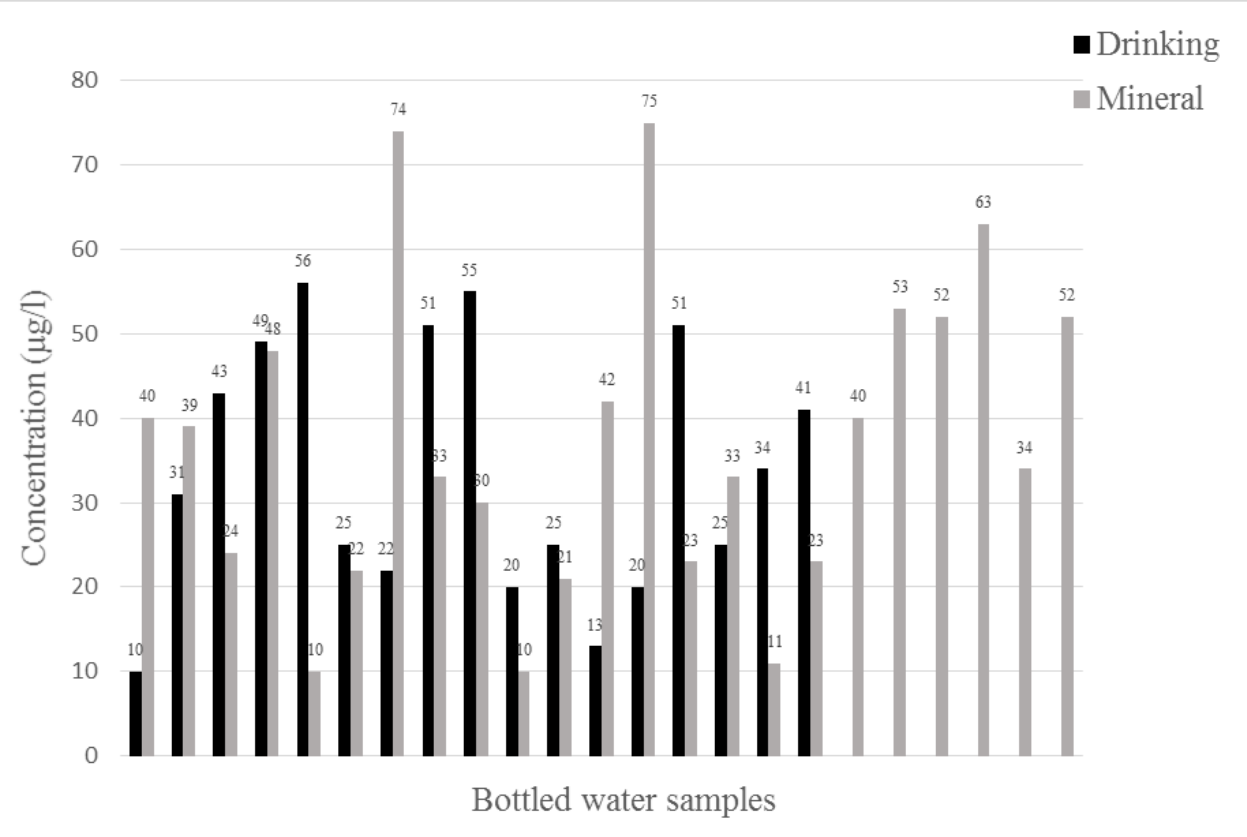

Figure 2. Amount of bromate in analyzed real samples higher than the MRL ( $n=17$ drinking, $n=23$ mineral) 


\section{Conclusions}

The ion chromatography technique is a reliable method for the determination of bromate and/or another anion. Depends on the matrix, conditions of methods should be validated and parameters optimized. Bromate determination, because of very low permissible level in national and international standards, needs to be able to detect in this range that IC technique could be appropriate for this purpose. The amount of bromate found in bottled water depends on the bromide content of the water source. Because of the potential contamination of their sources as well as the increasing oxygen content, it is permitted to apply ozone to halt the bromate formation. The tested mineral bottled water samples, originating from natural springs, based on standard national definitions, have slightly more bromate content than drinking bottled water samples. This may be caused by soil bed, comprising the high content of bromide. Additionally, the purification process of drinking bottled water could reduce bromide content, therefore resulting in decreased bromate formation. It should be noted that water with lower than $25 \mu \mathrm{g} / \mathrm{L}$ of bromide content has a bromate level which is not higher than the acceptable level. However, use of a disinfectant such as ozone could eliminate some contaminants, which may form secondary contaminants like bromate. Hence, special care should be taken in applying these compounds. The product safety of bottled water is extremely important for consumers and responsible authorities should inform and announce the possible hazards to the public. These results are useful in setting a standard level for bromate content in bottled water by an authorized organization such as Iran's Ministry of Health and the National Standard Organization.

\section{Acknowledgements}

We here by thank to personnel of General Directory of Food and Drug Reference Control Laboratories, Iran Food and Drug Administration (IFDA), Ministry of Health and Medical Education. Also South Tehran Branch of Islamic Azad University for technical and scientific supporting.

\section{ORCID}

Sima Djam: 0000-0001-8339-7688

Mostafa Najafi: 0000-0003-1297-8746

Seyyed Hamid Ahmadi: 0000-0002-1318-9581

Shahram Shoeibi: 0000-0002-5685-1213

\section{References}

[1] A. Astel, R. Michalski, A. Lyko, M. Jablonska-czapla, K. Bigus, S. Szopa and A. Kwiecinska (2014). Characterization of bottled mineral waters marketed in Poland using hierarchical cluster analysis, $J$. Geochem.Expl. 143, 136-145.

[2] Drinking water standards and health advisories (2012). United State Environmental Protection Agency (EPA).

[3] Packaged (bottled) Drinking water specifications (2010). Institute of Standards and Industrial Research of Iran (ISIRI 6694).

[4] M. Birke, C. Reimann, A. Demetriades, U. Rauch, H. Lorenz, B. Harazim and W. Glatte (2010). Determination of major and trace elements in European bottled mineral water analytical methods, $J$. Geochem. Expl. 107, 217-226.

[5] E.S. Gilchrist, D.A. Healy, V.N. Morris and J.D. Glennon (2016). A review of oxyhalide disinfection byproducts determination in water by ion chromatography and ion chromatography-mass spectrometry, Anal. Chim. Acta 942, 12-22.

[6] U. Von gunten (2003). Ozonation of drinking water: Part II. Disinfection and by-product formation in presence of bromide, iodide or chlorine, Water Res. 37, 1469-1487.

[7] F.Mashau, E.S. Ncube and K.Voyi (2018). Drinking water disinfection by products exposure and health effects on pregnancy outcomes: a systematic review, J. Water Health 167, 1-16. 
[8] E. Sawada, R. Fabris, A. Humpage and M. Drikas (2016) Effect of increasing bromide concentration on toxicity in treatment drinking water, J. Water Health 127, 183-191.

[9] Food and Drug Administration (2001). Fed. Reg. 66 (60), Beverages: Bottled Water, 16858-16868.

[10] E. Karadurmus, N. Taskin, E. Goz and M. Yuceer (2018). Prediction of bromate removal in drinking water using artificial neural network, Ozone: Sci. Eng: The J. Int. Ozone Assoc. 41, 118-127.

[11] I.V. Saradhi, S. Sharma, P. Prathibha and G.G. Pandit (2015). Oxyhalide disinfection by products in packaged drinking water and their associated risk, J. Curr. Sci. 108, 80-85.

[12] World Health Organization Guidelines for Drinking Water Quality, WHO, Geneva (2011). 4th Edition.

[13] X. Huang, N.Gao and Y.Deng (2008). Bromate ion formation in dark chlorination and ultraviolet/chlorination processes for bromide-containing water, J. Environ. Sci. 20, 246-251.

[14] A. Kumar, S. Rout and R.K. Singhal (2011). Health risk assessment for bromate $\left(\mathrm{BrO}_{3}^{-}\right)$traces in ozonated Indian bottled water, J. Environ. Prot. 2, 571-580.

[15] R. Buttler, A. Godley, L. Lytton and E. Carmell (2005). Bromate environmental contamination: review of impact and possible treatment, C. R. Environ. Sci. Technol. 35, 193-217.

[16] T. Myllykangas, T.K. Nissinen, A. Hirvonen, P. Rantakokko and T. Vartiainen (2007). The evaluation of ozonation and chlorination on disinfection by-product formation for a high bromide water, Sci. Eng. The J. Int. Ozone Assoc. 27, 19-26.

[17] Bromate in drinking water (2009). Background document for development of World Health Organization Guidelines for drinking water quality.

[18] Bromate in drinking water (2005). Background document for development of World Health Organization Guidelines for drinking water quality.

[19] D.T. Kimberly and E.M. Neal (2003). Activated carbon for bromate reduction, Water Qual. Prod., Water Wastes Digest. 12-14.

[20] S.A. Snyder, B.J. Vander ford and D.J. Rexing (2005). Trace analysis of bromate, chlorate, iodate, and perchlorate in natural and bottled waters, Environ. Sci. Technol. 39, 4586-4593.

[21] European Parliament and council Directive (2003). No.2003/40/EC, Establishing the List, Concentration Limits and Labeling Requirements for the Constituents of Natural Mineral Waters and the Conditions for Using Ozone-Enriched Air for the Treatment of Natural Mineral Waters and Spring Water.

[22] Toxicological review of Bromate (2001). U.S. Environmental Protection Agency, Washington, D.C.

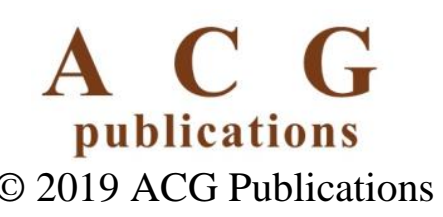

